\section{Do you have a bright idea?}

Do you have something to say to readers of the $B D J$ that doesn't quite fit into a letter to the editor? Do you have an idea that you would like to introduce to a wider audience, or would you like to start a debate on a particular topic that's been niggling at you for a while? If the answer to any of these questions is yes, we would like to invite you to write an Opinion article for the BDJ.

In Len D'Cruz's recent Opinion article Blue on blue, Len looked at the surprising number of referrals to the GDC Fitness to practise process by other colleagues. ${ }^{1}$ Just before Christmas, authors reflected on Professionalism in undergraduate dental education. ${ }^{2}$ Earlier in December Drs Walshaw, Kandiah and Rodd examined A trilogy of tragedies - paediatric tooth whitening. ${ }^{3}$

Opinion papers should be between 1,000 and 3,000 words long and can be submitted online (https://mts-bdj.nature.com/). If you have any questions or topic ideas you would like to discuss, the editorial team would love to hear from you.

\section{References}

1. D'Cruz L. Blue on blue. Br Dent J 2020; 228: 13-14.

2. Bateman H, Ellis J, McCracken G. Professionalism in undergraduate dental education: a pause for thought. Br Dent J 2019; 227: 1025-1027.

3. Walshaw $E$, Kandiah $P$, Rodd $H$. A trilogy of tragedies - paediatric tooth whitening Br Dent J 2019; 227: 959-960.

\section{By-election to the PEC of the BDA}

Nominations are sought for the following seat on the Principal Executive Committee (PEC):

\section{London (one seat)}

The PEC has overall responsibility for the control and direction of the policy and affairs of the BDA and its members are the directors of the Association.

There are 15 members on the PEC. Each will have a share of overall responsibilities, and typically this will require:

- Attendance at all meetings of the PEC - around five a year, but maybe more when business demands

- Attendance at own country council meetings - usually three a year

- Attendance at UK Council meetings - around two a year

- Sit on 1-2 sub committees/issue specific forums

- Attend general meetings of the Association.

It is anticipated that the approximate time commitment for a member of the PEC will be 20 days per year, with an annual remuneration of $£ 15,000$.

\section{Term of office}

This shall be until December 2022, with the opportunity to stand for a further full three-year term of office at that point.

\section{Induction, support and training}

Membership of the PEC carries significant organisational and legal responsibilities. There is an induction programme for those elected, and ongoing training. Members will also have advice and support from the Chief Executive and the wider BDA Team.

Next meetings of the PEC

Meetings of the PEC in 2020 are currently scheduled for:

Wednesday 6 May, Wednesday 15 July, Wednesday 23 September, Wednesday 2 December.

Nomination forms must be submitted online by 17.00 Friday 27 March 2020. A link to the online nomination portal can be found at www.bda.org/elections.

For more information about the elections to the PEC or the role of a PEC member please contact the BDA's Election Manager Stephen Skelton on 02075634141 or stephen.skelton@bda.org.

\section{BDA AGM}

The East of Scotland Branch AGM will be held on Wednesday 18 March 2020 at Royal Scots Club, 29-31 Abercrombie Place, Edinburgh, EH3 6QE, Scotland. The programme planned is as follows:

18:45-19:00 Registration and refreshments

19:00-19:15 East of Scotland AGM - all BDA members are encouraged to attend

19:15-20:45 Lecture and Q\&A - 'A long, happy and healthy career - addressing stress and burnout' with Roz McMullan, BDA President

To book please visit www.bda.org/bse. 